\title{
Alternative methodology for assessment of youth competitiveness in the labor market of Ukraine
}

\author{
Oksana Oliinyk $^{a}$, Iryna Lehan $^{\mathrm{a}}$, Larysa Sergiienko $^{\mathrm{a}}$, Larisa Kovalenko $^{\mathrm{b}}$ and Tetiana Tarasova ${ }^{\mathrm{c}^{*}}$
}

${ }^{a}$ Zhytomyr Polytechnic State University, Ukraine

${ }^{b}$ Yaroslav Mydryi National Law University, Ukraine

${ }^{c}$ Kharkiv State University of Food Technology and Trade, Ukraine

\section{H R O N I C L E}

\section{Article history:}

Received: February 15, 2020

Received in revised format:

March 162020

Accepted: March 16, 2020

Available online:

March 16, 2020

Keywords:

Labor market

Youth

Employment

Competitiveness

Education

\section{A B S T R A C T}

The purpose of the article is to substantiate an alternative methodology for assessing the competitiveness of young people in the labor market, based on the categories of transit from training to decent employment in the context of transformational change. The article explores the School-toWork Transition Survey (SWTS), which provides an opportunity to analyze the peculiarities of young people's transit to the labor market. The study was conducted within the framework of the "Work4Youth" project, which aimed to identify ways to obtain information concerning the labor market, namely its youth segment. The main purpose of the SWTS was to gather detailed information on the issues, attitudes and conditions in which young people aged 15-29 was entering and securing their jobs in the labor market. The competitiveness of young people in the labor market has been evaluated and the regions have been investigated according to the characteristics of the workplaces, where the state of completion of the transition from school to employment by the young person have been determined. In addition, clusters that are close in characteristics to the group of regions were distinguished.

C 2020 by the authors; licensee Growing Science, Canada

\section{Introduction}

In recent years, the issue of development and implementation of methodological and statistical tools has been actualized in Ukraine, which makes it possible to carry out an objective assessment of youth prospects in the labor market. Namely, it is a survey "School-to-Work Transition Survey" (SWTS) (Libanova et al., 2014), which provides an opportunity to analyze the peculiarities of young people's transit to the labor market. The SWTS survey in Ukraine was provided by the International Labor Organization's "Work4Youth" project (W4Y). The W4Y project aims to broaden the ways of obtaining information on the labor market, namely its youth segment. The main purpose of the SWTS was to gather detailed information on the issues, attitudes and conditions in which young people aged 15-29 is entering and securing their jobs in the labor market. The results of the SWTS survey can also be used to identify those individual characteristics of young people that determine success or failure in the labor market. This information is important for the development and implementation of a policy to prevent the risk of unemployment, as well as for measures to eliminate those factors that negatively affect the transition of young people to decent employment.

\section{Literature review}

Many scholars have made a significant contribution to the formation of modern theories and practices of labor market research, in particular (Libanova et al., 2014; Martiakova, 2012; Riabokon \& Puzenko, 2019; Stasiuk \& Bevz, 2012; Sabetska, 2018). They conceptualized the essence and content of the competitiveness of the labor market as a whole, defined the stages, components, characteristics of labor market research, explored various aspects of the application of technologies of the labor * Corresponding author.

E-mail address: tetianatarasova@ukr.net (T. Tarasova) 
market assessment to solve the applied assignments of its development. Gialis and Tsampra (2015) examined a variety of regional patterns of atypical employment in Greece with a focus on temporary employment and stated that the labor market should be flexible. Andersen (2012) argues that the development of a social protection network is necessary for the labor market to be stable. Gialis and Leontidou (2016) conducted a comparative analysis of flexibility and atypical employment in Greece, Italy and Spain. The uneven flexibility trends found in the countries studied are seen as a result of the interaction between general devaluation trends, different prerequisites and regional characteristics of the labor market adjustment, while employment is considered neither "rigid" nor "flexible". Samek (2019) examined gender competitiveness in hiring and concluded that this principle cannot be guided. Nemoto and Zuo (2017) examined informal employment in the Chinese labor market. Zuo (2013) found that job probability is determined mainly by gender, age, experience, ethnicity, education, region and migrant status, whereas the monthly wages of informal workers are mainly influenced by education, region, firm size, city size and migrant status (Ievdokymov et al., 2020). Van Aerden et al. (2016) focused their research on the relationship between employment quality and the well-being of European employees, using data from the 2010 European Working Conditions Survey. The results show that quality of employment is defined as an important social determinant of health in Europe. Benach et al. (2016) developed the protocol "What should we know about precarious employment and health in 2025?". Storm and Naastepad (2015) described how Germany formed a competitive labor market during the crisis, with young people as the main ones. In their work, Kinash et al. (2019) argued that science and education are a reliable segment for disseminating innovation, as they can foster decent employment for the younger generation by providing them with relevant competencies and skills. Dovgal et al. (2017) suggested a competitiveness assessment matrix that enables a more detailed analysis of the opportunities and prospects of strategic choice in the labor market. Cherchata et al. (2020) claimed that establishing good business processes in the country helps to increase the level of competitiveness in the youth labor market. However, the structural and dynamic changes taking place in the labor market require constant up-to-date research, in particular in the context of ensuring the resilience of young people in the labor market and the alternative of assessing its competitiveness, which determines the relevance and timeliness of the research topic and its practical relevance.

The purpose of the article is to substantiate an alternative methodology for assessing the competitiveness of young people in the labor market, based on the categories of transit from training to decent employment in the context of transformational change.

\section{Results and discussion}

According to the authors of the study, the steps that characterize the transition of young people to the labor market is an objective indicator of their competitiveness. The transition of young people into the labor market can be assessed not only by the time between graduation (with or without a diploma) and finding any first job, but also by qualitative characteristics. Thus, the survey of young people's transition to the labor market relies on a more rigorous definition of what can be considered a worthy end of the job search - stable employment than usual. The traditional definition of completing the transition to the job market is getting a first job. The methodological foundations of the study of Sabetska (2018) suggest a qualitatively new approach, where it is believed that a person has not completed the "transition" to the labor market until he / she receives a job that meets the basic criteria of stability and duration of the employment contract. On the other hand, the situation is quite widespread when not all young people in Ukraine have achieved stable employment, although their "ultimate goal" in relation to their place in the labor market has been achieved. Perhaps the approach to form categories solely at an angle to the stability parameters evaluated, so to speak, "from the outside", is too narrow. For this reason, the ILO recommends paying attention to job satisfaction criteria and incorporating them into the concept of transition to the labor market. Thus, the transition to the labor market is defined as moving a young person from the end of their studies (or their first economic activity), or to the first stable job, or a satisfying one. The stability of employment is determined in terms of the legal guarantee of the employment contract (written or oral) and its validity (more than 12 months). Having an employment contract automatically eliminates self-employment when employment relationships are not treated as employment relationships. The opposite of stable employment is temporary employment and paid employment for less than 12 months. Employment satisfaction is a subjective criterion based on the self-esteem of an employed person. This means that the respondent considers his / her employment to be in line with its requirements and the purpose of employment. In contrast, employment is unsatisfactory when the respondent is not satisfied with it (Sabetska, 2018). Based on the meaning of the term "transition to the labor market", the transition stages are classified as follows:

1. People who transited are young people who are currently employed as:

- hired employees who have a stable job, whether they are satisfied or dissatisfied with the job;

- hired employees who have temporary job and are satisfied with their job;

- self-employed, satisfied with their job.

2. People in transition - young people:

- unemployed in the broadest sense (according to weakened criteria);

- employees who have temporary job and are not satisfied with it;

- self-employed, dissatisfied with their employment;

- economically inactive young people who do not study anywhere but want to find a job later. 
3. People whose transition has not yet begun, young people belonging to one of the statuses of economically inactive youth: - still studying;

- they do not study anywhere and do not seek work later.

Two aspects of this classification are noteworthy. First, the duration of the transition between opposite poles of economic activity is determined by the standard methodology of the workforce concept. The category "persons completing the transition" includes exclusively young people who are classified as employed. Other people in employment are in the "transition" category - unemployed and part of economically inactive youth who are unemployed but ready to start, although they are not actively looking for job and those inactive who are not studying anywhere, are not looking job, but aim to do it later. The "people who have not started transition" category includes those inactive who are not in the other categories. Secondly, the stages of transition are a scientific classification that is not yet used as a normative or alternative. Due to the inclusion of young people who are satisfied with self-employment and temporary employment, it cannot be said that all young people in the category of persons who completed the transition received the highest quality employment. In fact, many young selfemployed, free-of-charge family members, and even those employees whose informal employment is a significant proportion of the unstable employment.

Yet, they have expressed satisfaction with their work, and have probably completed their transition in the sense that they want to remain self-employed for another part of their working lives. It is important to note that the classification of transition stages is aimed at introducing the concept of flow into the labor market studies. A person is in the process of transition until he or she has reached a stable position in the labor market; those who complete the transition have been given a job they are likely to try to keep, whether or not it is satisfactory. The paper suggests an approach to assess the competitiveness of young people, based on the categories of transit from study to decent employment, and relevant survey data, according to which young people who completed the transit are in the competitive area. When young people reach working age, they have a number of alternative behaviors in the labor market, which include training scenarios for the proposed vocational education system, a list of specialties by specific vocational education, work or a combination of training and work. The ultimate goal for the young person is to complete the transition to the labor market. In our opinion, the transit process as a set of episodes of training, transitions from one workplace to another, as well as directly to work is a reflection of the process of competitiveness formation. That is, after completing the transit, the young man has a formed primary competitiveness, confirmed by quantitative and qualitative criteria. In doing so, it joins competitive adults in the workforce. Thus, if the fact of completing the transition from education to decent employment is to be used as a criterion for competitiveness in the labor market, then it is possible to evaluate the competitiveness of young people aged 15-29 by quantitative and qualitative criteria.

The analysis of the database of the project "Transition to the labor market of youth of Ukraine" allows to create a statistical base for the study of competitiveness of youth in the regions of Ukraine in order to classify them into groups on the quantitative and qualitative criterion of completing the transition to the labor market. The specificity of the aforementioned database is the dominance of nominal data in its structure, which is natural for the result of a sociological survey, but complicates their analysis in terms of revealing statistical relationships between them. The most appropriate tool for identifying relationships between nominal data is the analysis of frequency or conjugate tables, based on which one can give an idea of the connection (as a common occurrence) of certain values of one trait with some values of other traits. Since in addition to frequencies as observed values, it is possible to calculate the expected values for each cell of the table in the conjunction table, this expected value is calculated based on the assumption that two nominal variables are independent.

By comparing the expected frequencies with the observed frequencies, it is possible to draw conclusions about whether the two nominal characteristics are truly independent. The greater the discrepancy between the observed and expected frequencies, the stronger the relationship between the features. To determine the degree of correspondence between the observed values and the expected values, the "Chi-square" criterion $\left(\chi^{2}\right)$ is used, which is defined as the sum of the ratio of the squared deviations of the observed value $\left(f_{0}\right)$ to that expected $\left(f_{\mathrm{e}}\right)$ in each cell of the table (Sabetska, 2018):

$$
\chi^{2}=\Sigma\left[\left(f_{0}-f_{\mathrm{e}}\right)^{2} / f_{\mathrm{e}}\right]
$$

As can be seen from the formula, for large deviations of values of $f_{0}$ from $f_{\mathrm{e}}$, the value of $\chi^{2}$ also becomes large. Together with $\chi^{2}$, the p-level of significance is calculated. At $p>0,05$, the difference between observed and expected values is considered to be insignificant. Otherwise, the assumption that two nominal variables are independent is rejected, and it is concluded that the two variables are interdependent (Sabetska, 2018).

Using this analytical toolkit, we will conduct research on the presence of a number of dependencies. First, let's formulate an idea of the answer to the question: Is there a relationship between the fact of completion of the transition and the fact of residence in a particular region. Table 1 provides relevant information on the relationship between the two Transit Completed and Region variables. Separately, the Transit Completed variable was synthesized in the database structure and subjected to a dichotomization procedure (i.e. conversion to a binary variable). 
Table 1

Analysis of the relationship between the Transit Completed and Region variables

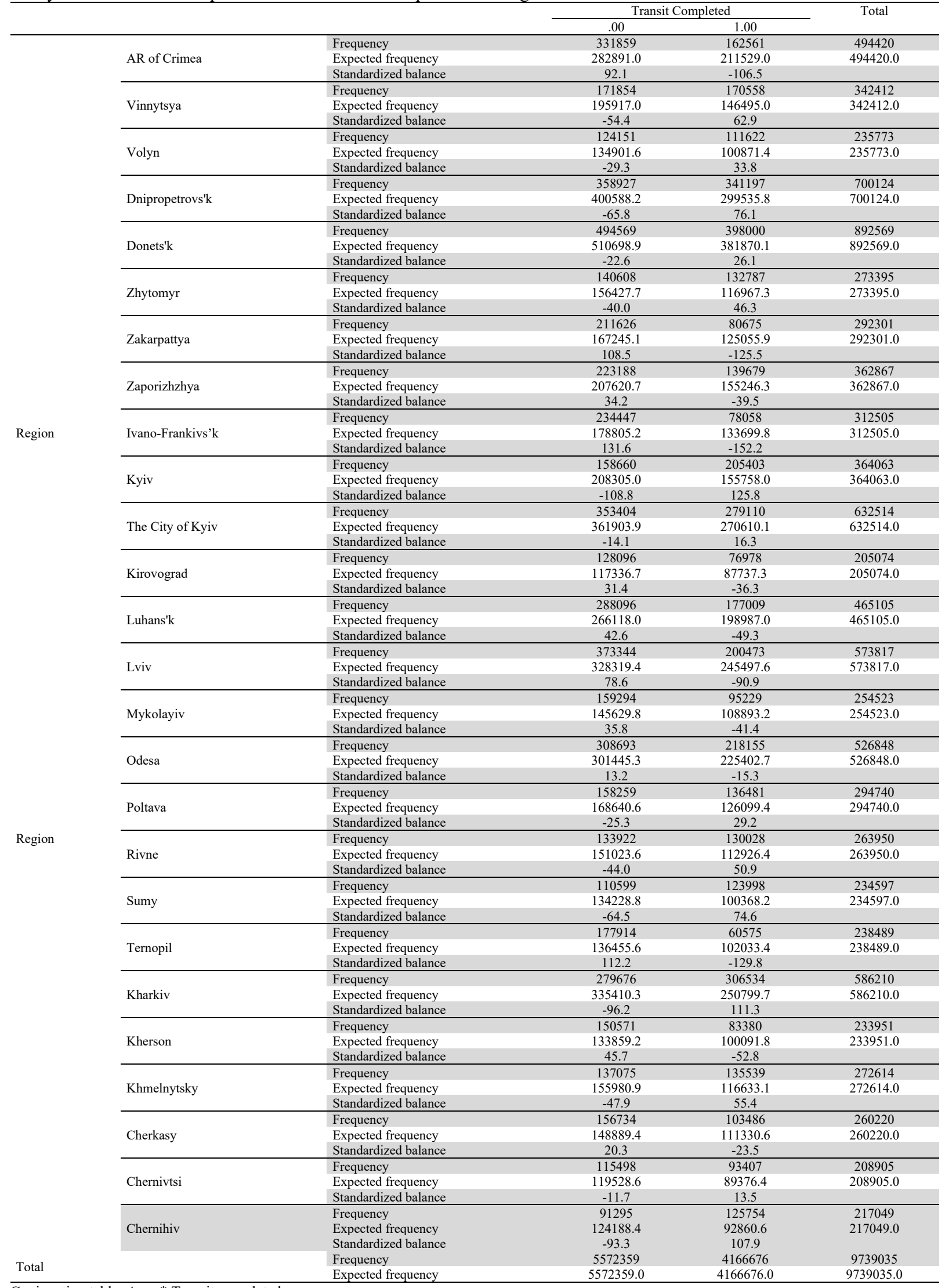

Conjugation table: Area * Transit completed 
By identifying a separate Transit Completed variable in the data structure and subjecting it to a dichotomization procedure (that is, converting it to a binary variable), a connection type was identified to analyze the relationship between the nominal data. Analysis of the results of the study protocol allows us to conclude that the variables "Transit completed" and "Region" are: estimated $\chi^{2}=265725,7$, and its critical value at 44,31410 (at $n=25$ and $p=0,01$ ), i.e. is much smaller, which allows us to reject the null hypothesis of independence. Thus, fundamentally the existence of a link between the fact of completion of transit and residence in a certain region is confirmed, but the statistical estimate of this relationship can be defined as very weak - the value of the Phi and Cramer coefficients is 0.165 , while rejecting the assumption that there is a linear connection. Analyzing the Ukrainian database (Tsymbal \& Yarosh, 2015) on the transit of young people from education to decent employment, it can be determined that in general across Ukraine according to 2018 data, $42.8 \%$ of young people aged from 15 to 29 completed the transit (Table 2).

Table 2

Transition stage based on gender, age, place of residence and education level (in percentage

\begin{tabular}{|c|c|c|c|c|}
\hline Indicator & Transit Completed & $\begin{array}{l}\text { In the process of tran- } \\
\text { sition }\end{array}$ & Transition not started & Total \\
\hline Total & 42.6 & 22.8 & 34.3 & 100.0 \\
\hline \multicolumn{5}{|c|}{ Gender } \\
\hline Male & 47.9 & 18.7 & 33.1 & 100.0 \\
\hline Female & 37.1 & 27.0 & 35.5 & 100.0 \\
\hline \multicolumn{5}{|c|}{ Age group } \\
\hline $15-19$ years & 7.1 & 15.0 & 77.9 & 100.0 \\
\hline $20-24$ years & 42.5 & 26.6 & 30.9 & 100.0 \\
\hline 25-29 years & 68.6 & 24.8 & 6.6 & 100.0 \\
\hline \multicolumn{5}{|c|}{ Place of residence } \\
\hline Urban settlements & 44.9 & 20.5 & 34.3 & 100.0 \\
\hline Countryside & 37.3 & 28.0 & 34.2 & 100.0 \\
\hline \multicolumn{5}{|c|}{ Education (only those who have completed education) } \\
\hline Primary and secondary education & 18.2 & 81.8 & 0.0 & 100.0 \\
\hline Completed secondary school & 44.5 & 47.9 & 7.6 & 100.0 \\
\hline Professional and technical & 63.6 & 33.7 & 2.7 & 100.0 \\
\hline Higher Education & 73.2 & 24.6 & 2.2 & 100.0 \\
\hline Postgraduate education & 75.9 & 24.1 & 0.0 & 100.0 \\
\hline
\end{tabular}

Source: Compiled by authors based on (Tsymbal \& Yarosh, 2015; Nasledov, 2011).

According to the authors of the study (Nasledov, 2011) the most significant factors in completing the transit to the labor market are education level, household financial status, gender and place of residence. Young men are more likely to complete the transition: their share is $47.9 \%$, and women who complete the transition are $37.1 \%$. Urban youth are more likely to complete the transition to the labor market than rural youth (44.9\% and $37.3 \%$, respectively). By region, the most successful in the labor market (Table 3) are young people living in Chernihiv, Kyiv, Sumy, Kharkiv, Vinnitsa regions.

Table 3

Regions of Ukraine by stages of transition of young people from study to employment

\begin{tabular}{|c|c|c|c|c|}
\hline \multirow{2}{*}{ Region } & \multicolumn{3}{|c|}{ Stage of transition } & \multirow{2}{*}{ Total } \\
\hline & Transit Completed & In the process of transition & Transition not started & \\
\hline AR of Crimea & $32.9 \%$ & $20.9 \%$ & $46.2 \%$ & $100.0 \%$ \\
\hline Vinnytsya & $49.8 \%$ & $19.9 \%$ & $30.3 \%$ & $100.0 \%$ \\
\hline Volyn & $47.3 \%$ & $21.8 \%$ & $30.8 \%$ & $100.0 \%$ \\
\hline Dnipropetrovs'k & $48.7 \%$ & $21.2 \%$ & $30.1 \%$ & $100.0 \%$ \\
\hline Donets'k & $44.6 \%$ & $16.5 \%$ & $38.9 \%$ & $100.0 \%$ \\
\hline Zhytomyr & $48.6 \%$ & $21.0 \%$ & $30.4 \%$ & $100.0 \%$ \\
\hline Zakarpattya & $27.6 \%$ & $33.0 \%$ & $39.4 \%$ & $100.0 \%$ \\
\hline Zaporizhzhya & $38.5 \%$ & $29.6 \%$ & $31.9 \%$ & $100.0 \%$ \\
\hline Ivano-Frankivs'k & $25.0 \%$ & $41.2 \%$ & $33.9 \%$ & $100.0 \%$ \\
\hline Kyiv & $56.4 \%$ & $17.2 \%$ & $26.3 \%$ & $100.0 \%$ \\
\hline The City of Kyiv & $44.1 \%$ & $23.9 \%$ & $32.0 \%$ & $100.0 \%$ \\
\hline Kirovograd & $37.5 \%$ & $23.1 \%$ & $39.3 \%$ & $100.0 \%$ \\
\hline Luhans'k & $38.1 \%$ & $22.5 \%$ & $39.5 \%$ & $100.0 \%$ \\
\hline Lviv & $34.9 \%$ & $22.6 \%$ & $42.4 \%$ & $100.0 \%$ \\
\hline Mykolayiv & $37.4 \%$ & $36.5 \%$ & $26.1 \%$ & $100.0 \%$ \\
\hline Odesa & $41.4 \%$ & $24.9 \%$ & $33.6 \%$ & $100.0 \%$ \\
\hline Poltava & $46.3 \%$ & $16.2 \%$ & $37.5 \%$ & $100.0 \%$ \\
\hline Rivne & $49.3 \%$ & $16.6 \%$ & $34.1 \%$ & $100.0 \%$ \\
\hline Sumy & $52.9 \%$ & $7.5 \%$ & $39.6 \%$ & $100.0 \%$ \\
\hline Ternopil & $25.4 \%$ & $41.2 \%$ & $33.4 \%$ & $100.0 \%$ \\
\hline Kharkiv & $52.3 \%$ & $19.1 \%$ & $28.6 \%$ & $100.0 \%$ \\
\hline Kherson & $35.6 \%$ & $37.7 \%$ & $26.6 \%$ & $100.0 \%$ \\
\hline Khmelnytsky & $49.7 \%$ & $20.0 \%$ & $30.3 \%$ & $100.0 \%$ \\
\hline Cherkasy & $39.8 \%$ & $16.3 \%$ & $43.9 \%$ & $100.0 \%$ \\
\hline Chernivtsi & $44.7 \%$ & $31.3 \%$ & $24.0 \%$ & $100.0 \%$ \\
\hline Chernihiv & $57.9 \%$ & $11.6 \%$ & $30.5 \%$ & $100.0 \%$ \\
\hline Total & $42.8 \%$ & $22.8 \%$ & $34.4 \%$ & $100.0 \%$ \\
\hline
\end{tabular}

Source: Compiled by authors based on (Andrusiv et al., 2020) 
Mykolaiv, Kherson, Lviv, Autonomous Republic of Crimea, Zakarpattya, Ternopil, Ivano-Frankivsk regions are closing the rating. In this case, as can be seen from the graph shown in Fig. 1, regions are divided into two groups that are almost identical in terms of the average for Ukraine.

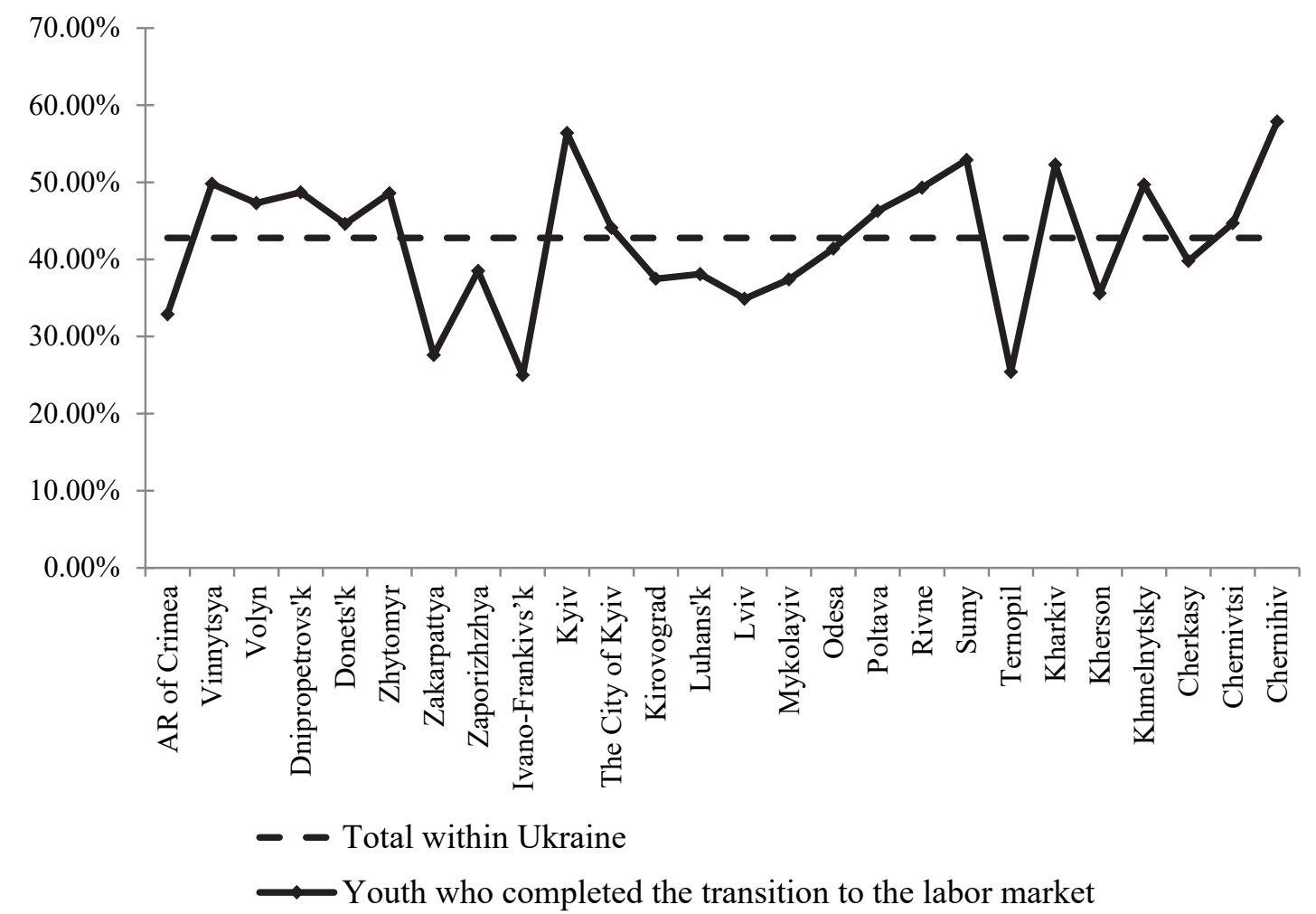

Fig. 1. Number of young people aged 15-29 who completed the transition to the labor market by regions of Ukraine

To formalize the assessment of the regions of Ukraine by competitiveness of young people in the labor market, we will make the following transformation: we will give the percentage of young people who completed the transition to the labor market the value of a grade assessment of competitiveness, thus obtaining the corresponding estimates $K_{i}$ youth competitiveness in the labor market by regions, where $i$ is substring index denoting a specific region $(i=1 \ldots 26)$. We will determine the ratings of the regions of Ukraine and give a description of the corresponding rating. To interpret the obtained competitiveness estimates, we use an interval scale that breaks the resulting assessment range into 3 separate groups, identifying regions with low, medium, and high levels of assessment (Table 4).

Table 4

The scale of assessing the competitiveness of young people in the labor market

\begin{tabular}{cc}
\hline Rating interval & Characteristics of competitiveness assessment \\
\hline from $K_{i}^{\text {min }}$ till $K_{i}^{\text {min }}+h$ & Low level \\
from $K_{i}^{m_{i n}}+h$ till $K_{i}^{m i n}+2 h$ & Average level \\
from $K_{i}^{\text {min }^{m}}+2 h$ till $K_{i}^{\text {min }}+3 h$ & High level \\
\hline
\end{tabular}

Source: developed by the authors

The size of the interval is calculated as the difference between the maximum and minimum values of the obtained estimate among all regions divided by the number of separated groups, namely:

$$
h=\frac{\left(K_{i}^{\max }-K_{i}^{\min }\right)}{r},
$$

where: $h$ - the size of the interval; $K_{i}^{\max }$ - the maximum value of the integral estimate; $K_{i}^{\min }$ - the minimum value of the integral estimate; $r$-number of separated groups, $(r=3)$. Vinnytsya, Volyn, Dnipropetrovs'k, Zhytomyr, Kyiv, Rivne, Sumy, Kharkiv, Khmelnytsky, and Chernihiv regions are included in the high-ranking group of regions. The indicators of the Autonomous Republic of Crimea, Zakarpattya, Ivano-Frankivsk, Lviv, Ternopil and Kherson regions are characterized by low levels. The indicators of the rest of the regions correspond to the average level of assessment of youth competitiveness in the labor market. Transit completeness from training to employment is defined, on the one hand, as a young person's willingness (readiness) to take the appropriate workplace and productively, effectively work, and, on the other hand, the availability of suitable jobs, 
which by their characteristics must be attractive and desirable for employees. The results of the calculations are shown in Table 5.

Table 5

Assessment of youth competitiveness in the labor market by regions of Ukraine

\begin{tabular}{|c|c|c|c|c|}
\hline \multirow[t]{2}{*}{ Number $(i)$} & \multirow[t]{2}{*}{ Region } & \multicolumn{3}{|c|}{ Assessment of youth competitiveness in the labor market } \\
\hline & & Score $\left(K_{i}\right)$ & Rank & Characteristics of evaluation \\
\hline 1. & AR of Crimea & 32.90 & 23 & low \\
\hline 2. & Vinnytsya & 49.80 & 5 & high \\
\hline 3. & Volyn & 47.30 & 10 & high \\
\hline 4. & Dnipropetrovs'k & 48.70 & 8 & high \\
\hline 5. & Donets'k & 44.60 & 13 & average \\
\hline 6. & Zhytomyr & 48.60 & 9 & high \\
\hline 7. & Zakarpattya & 27.60 & 24 & low \\
\hline 8. & Zaporizhzhya & 38.50 & 17 & average \\
\hline 9. & Ivano-Frankivs’k & 25.00 & 26 & low \\
\hline 10. & Kyiv & 56.40 & 2 & high \\
\hline 11. & The City of Kyiv & 44.10 & 14 & average \\
\hline 12. & Kirovograd & 37.50 & 19 & average \\
\hline 13. & Luhans'k & 38.10 & 18 & average \\
\hline 14. & Lviv & 34.90 & 22 & low \\
\hline 15. & Mykolayiv & 37.40 & 20 & average \\
\hline 16. & Odesa & 41.40 & 15 & average \\
\hline 17. & Poltava & 46.30 & 11 & average \\
\hline 18. & Rivne & 49.30 & 7 & high \\
\hline 19. & Sumy & 52.90 & 3 & high \\
\hline 20. & Ternopil & 25.40 & 25 & low \\
\hline 21. & Kharkiv & 52.30 & 4 & high \\
\hline 22. & Kherson & 35.60 & 21 & low \\
\hline 23. & Khmelnytsky & 49.70 & 6 & high \\
\hline 24. & Cherkasy & 39.80 & 16 & average \\
\hline 25. & Chernivtsi & 44.70 & 12 & average \\
\hline 26. & Chernihiv & 57.90 & 1 & high \\
\hline
\end{tabular}

In view of this, we consider it necessary to investigate the regions by the characteristics of the workplaces, which determined the state of completion of the young person's transition from study to employment, while separating the similar characteristics of the group of regions, that is, to carry out clustering. We chose these characteristics as the distribution of specialties according to the Standard Industrial Classification code classification, the educational and qualification level, which appeared to be required for carrying out the relevant professional activity, as well as the distribution of jobs by type of locality. To accomplish this task, it is necessary to create an appropriate database for clustering. Further analysis of the SWTS database allows us to identify the set of observations that fit the category of completed transit and to examine their individual characteristics by regional context. We will group the received data corresponding to the observations, classified by the completed transit, into a single database by regions and Kyiv.

\section{Cluster 1.1 Hierarchical clustering of regions of Ukraine}

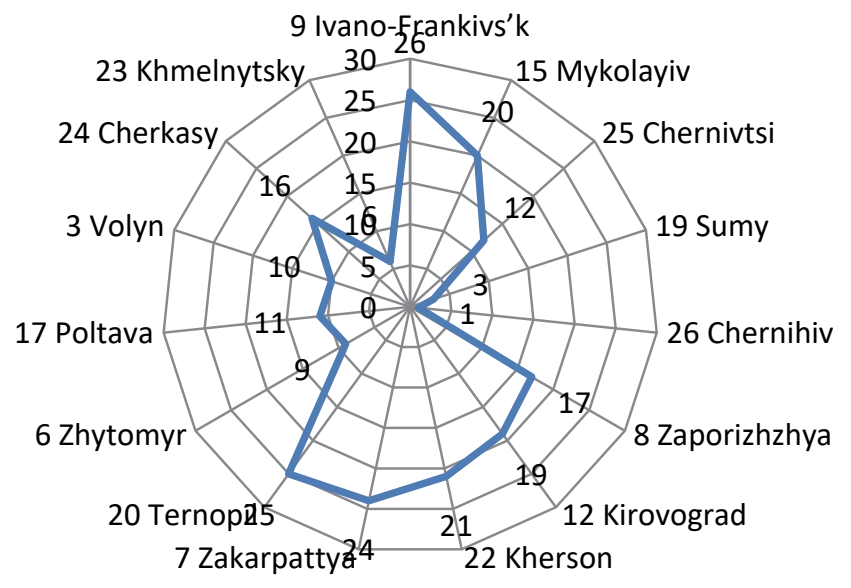

Fig. 1 Cluster 1. 1 
Cluster 1.2 Hierarchical clustering of regions of Ukraine

13.

1.

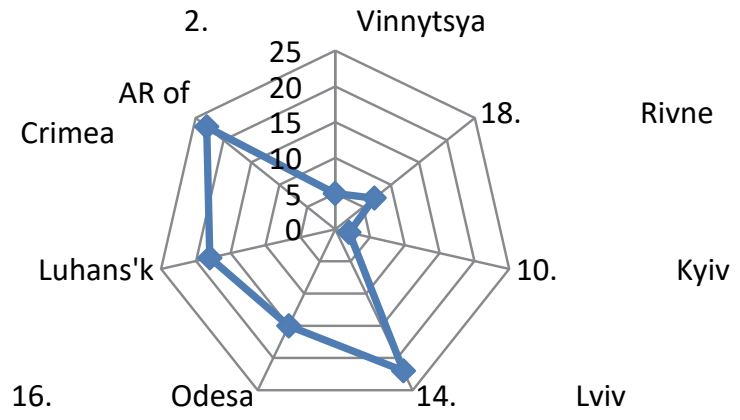

Fig. 2. Cluster 1.2

\section{Cluster 2 Hierarchical clusțtering of regions of Ukraine}

Dnipropetrovs'k

21.

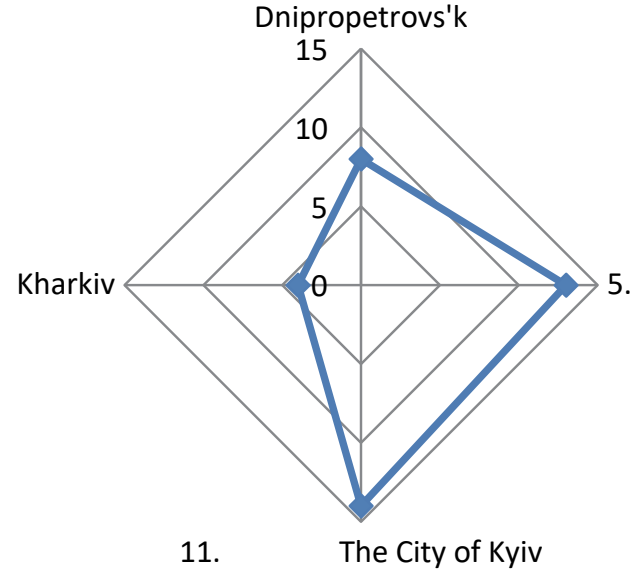

Donets'k

Fig. 3. Cluster 2

As all the obtained data are frequencies, i.e. they have the same dimension, standardization of the obtained indicators was not carried out. Cluster analysis was performed using IBM SPSS Statistics 20. The analysis showed that most clearly the structure of connections and the closeness between the individual regions is represented in the hierarchical clustering by the method of "farthest neighbor" (Complete linkage method), i.e. the so-called full connection method: the inclusion of an object in the cluster is carried out in the presence of a measure of similarity of not less than a certain critical value, and the distance between the two clusters is defined as the distance between the farthest values, with each observation taken from their cluster. The clustering was performed using the Euclidian distance between the objects in the corresponding calculations. The breakdown of the regions of Ukraine into clusters according to the characteristics of the jobs at which the transit completion determines is presented in Figs. 1-3. From the graphical representation of the results of the analysis, it can be seen that the regions of Ukraine formed two unequal clusters: a large cluster 1, which can be divided into two subclusters: cluster 1.1, which consists of IvanoFrankivs'k, Mykolayiv, Chernivtsi, Sumy, Chernihiv, Zaporizhzhya, Kirovograd, Kherson, Zakarpattya, Ternopil, Zhytomyr, Poltava, Volyn, Cherkasy, Khmelnytsky regions and cluster 1.2 which consists of Binnytsya, Rivne, Kyiv, Lviv, Odesa, Luhans'k regions and Crimea. As well as cluster 2, which includes the other three regions: Dnipropetrovs'k, Donetsk, Kharkiv and Kyiv.

In the cluster 1.1. the closest in terms of jobs, which occupation allowed young people to consider their transits completed, are Ivano-Frankivs'k, Mykolayiv and Chernivtsi regions. Another core of the clustering was the Kirovograd and Kherson regions, and the Zakarpattya and Ternopil regions, as well as Volyn and Cherkasy, are close in terms of their respective characteristics. The formation of cluster 1.2 begins with the unification of Vinnytsya and Rivne regions, as well as Lviv and Odesa. These two pairs are the closest and similar in character to the objects in this group. Cluster 2 begins with the union of Dnipropetrovs'k and Donets'k regions, but they are not as close to each other as the above. In general, it can be concluded that cluster 2 includes the economically most developed regions, with clustering showing their originality both in the middle of this group and in relation to other regions of Ukraine. Accordingly, it can be assumed that more differentiated labor market 
development strategies should be applied to the areas within the second cluster than to the rest of the regions. In general, a more detailed analysis based on the classification can form the main types of development strategies for the obtained groups of regions.

\section{Conclusion}

Thus, the suggested methodology for assessing competitiveness in the regional context made it possible to carry out a comprehensive analysis, monitoring and ranking of the regions of Ukraine by the level of competitiveness of young people in the labor market, as well as to determine the priority areas and tasks of development of both regional and state, youth labor market and increase its competitiveness. The results of the calculations are intended to be used to analyze the state of providing regions with a competitive workforce and to justify the policy of socio-economic development of Ukrainian regions.

\section{References}

Andersen, T. M. (2012). A flexicurity labour market in the great recession: The case of Denmark. Economist, 160(2), 117140 .

Andrusiv, U., Simkiv, L., Dovgal, O., Demchuk, N., Potryvaieva, N., Cherchata, A., Popadynets, I., Tkachenko, G., Serhieieva, O \& Sydor, H. (2020). Analysis of economic development of Ukraine regions based on taxonomy method. Management Science Letters, 10(3), 515-522.

Cherchata, A., Popovychenko, I., Andrusiv, U., Simkiv, L., Kliukha, O \& Horai, O. (2020). A methodology for analysis and assessment of business processes of Ukrainian enterprises. Management Science Letters , 10(3), 631-640.

Benach, J., Vives, A., Tarafa, G., Delclos, C., \& Muntaner, C. (2016). What should we know about precarious employment and health in 2025? framing the agenda for the next decade of research. International Journal of Epidemiology, 45(1), 232-238.

Dovgal, O.V., Kravchenko, M.V., Demchuk, N.I., Odnoshevnaya, O.A., Novikov, O.Y., Andrusiv, U.Y., Lesik, I.M. \& Popadynets, I.R. (2017). Methods of competitiveness assessment of agricultural enterprise in Eastern Europe, Regional Science Inquiry, 9(2), 231-242.

Gialis, S., \& Leontidou, L. (2016). Antinomies of flexibilization and atypical employment in mediterranean europe: Greek, italian and spanish regions during the crisis. European Urban and Regional Studies, 23(4), 716-733.

Gialis, S., \& Tsampra, M. (2015). The diverse regional patterns of atypical employment in greece: Production restructuring, re/deregulation and flexicurity under crisis. Geoforum, 62, 175-187.

Ievdokymov, V., Lehenchuk, S., Zakharov, D., Andrusiv, U., Usatenko, O \& Kovalenko, L. (2020). Social capital measurement based on "The value explorer" method. Management Science Letters, 10(6), 1161-1168.

Kinash, I., Andrusiv, U., Golovnia, O \& Popadynets, I. (2019). Aspects of the formation and development of innovation infrastructure in Ukraine. Management Science Letters, 9(13), 2403-2414.

Libanova, E., Tsymbal, O., Lisohor, L., Marchenko, I., Yarosh, O. (2014). Transition to the Youth Labor Market of Ukraine. International Labor Office, Youth Employment Program, Employment Policy Department, Geneva: ILO, 93 p.

Martiakova, O. (2012). Interaction between Labor Markets and Educational Services: Trends and Prospects. Sustainable Economic Development, 7, pp. 19-24.

Nasledov, A. (2011). SPSS 19: Professional Statistical Analysis of Data. St. Petersburg: Peter, 400 p.

Nemoto, J., \& Zuo, H. (2017). Is informal employment a result of market segmentation? evidence from china. Australian Economic Review, 50(3), 309-326.

Riabokon, I., Puzenko, D. (2019). Relationship between Quality of Working Life and Motivation of Employees in Enterprises. Bulletin of Kamyanets-Podilskyi Ivan OgiyenkoNationalUniversity. Economic Sciences Series, 14, 376 -382.

Sabetska, T. (2018). Social Responsibilityas a Philosophy of Formation of Effective Personnel Policy of the Enterprise. Economy and the State, 4, 53-57.

Samek, A. (2019). Gender differences in job entry decisions: A university-wide field experiment. Management Science, 65(7), 3272-3281. doi:10.1287/mnsc. 2018.3107

Stasiuk, O., Bevz, I. (2012). Integral Assessment of the Competitiveness of Ukrainian Regions. Economics and Forecasting, $1,75-86$.

Storm, S., \& Naastepad, C. W. M. (2015). Crisis and recovery in the german economy: The real lessons. Structural Change and Economic Dynamics, 32, 11-24.

Tsymbal, O., Yarosh, O. (2015). Current Issues of Achieving Decent Employment of the Youth of Ukraine: An Analytical Note. K.: The Institute of Demography and Social Research named by M.V. Ptukha of NAS of Ukraine, 25 p.

Van Aerden, K., Puig-Barrachina, V., Bosmans, K., \& Vanroelen, C. (2016). How does employment quality relate to health and job satisfaction in europe? A typological approach. Social Science and Medicine, 158, 132-140.

Zuo, H. (2013). Formal and informal employment in china: Probability of employment and determinants of monthly wages. Australian Economic Review, 46(4), 405-423. 
(C) 2020 by the authors; licensee Growing Science, Canada. This is an open access article distributed under the terms and conditions of the Creative Commons Attribution (CC-BY) license (http://creativecommons.org/licenses/by/4.0/). 